\title{
STUDIES IN SOGIOLOGY
}

This series, prepared under the auspices of the British Sociological Association, is designed to provide short but comprehensive and scholarly treatments of key problem-areas in sociology. The books do not offer summary accounts of the current state of research in various fields, but seek rather to analyse matters which are the subject of controversy or debate. The series is designed to cover a broad range of topics, falling into three categories: (1) abstract problems of social theory and social philosophy; (2) interpretative questions posed by the writings of leading social theorists; (3) issues in empirical sociology. In addition, the series will carry translations of important writings in sociology which have not previously been available in English. Each book makes a substantive contribution to its particular topic, while at the same time giving the reader an indication of the main problems at issue; each carries an annotated bibliography, comprising a critical survey of relevant further literature.

University of Cambridge

Anthony Giddens 


\section{STUDIES IN SOGIOLOGY}

General Editor: Anthony Giddens

Editorial Advisers: T. B. Bотtomore, David LoGkwood and Ernest Gellner

\section{Published}

POLITICS AND SOCIOLOGY IN THE THOUGHT OF MAX WEBER

Anthony Giddens

PROFESSIONS AND POWER

Terence J. Johnson

THE SOGIAL PROGESS OF INNOVATION: A STUDY IN THE SOCIOLOGY OF SGIENCE

M. J. Mulkay

Forthcoming

THE SOCIOLOGY OF SOCIAL MOVEMENTS

J. Banks

MARXIST SOGIOLOGY

T. B. Bottomore

MATHEMATICS AND SOGIOLOGY

B. Hindess

STRIKES AND INDUSTRIAL CONFLICT

G. Ingham

THE DEVELOPMENT OF THE SOGIOLOGY OF KNOWLEDGE

S. Lukes

GONFLICT AND GOHESION IN THE WESTERN WORKING CLASS

M. Mann

MIGHELS AND THE GRITIQUE OF SOGIAL DEMOGRACY

F. Parkin 


\section{Politics and Sociology \\ in the Thought of Max Weber}

\section{ANTHONY GIDDENS}

Lecturer in Sociology, University of Cambridge 
ISBN 978-0-333-13436-8 ISBN 978-1-349-01456-9 (eBook) DOI 10.1007/978-1-349-01456-9

(C) British Sociological Association 1972

Reprint of the original edition 1972

All rights reserved. No part of this publication may be reproduced or transmitted, in any form or by any means, without permission.

\author{
First published 1972 by \\ THE MAGMILLAN PRESS LTD \\ London and Basingstoke \\ Associated companies in New York Toronto \\ Dublin Melbourne Johannesburg and Madras
}

SBN 333134362

The paperback edition of this book is sold subject to the condition that it shall not, by way of trade or otherwise, be lent, re-sold, hired out, or otherwise circulated without the publisher's prior consent, in any form of binding or cover other than that in which it is published and without a similar condition including this condition being imposed on the subsequent purchaser. 


\section{GONTENTS}

Acknowledgements and Bibliographical Note $\quad 6$

1 Introduction 7

2 Main Themes in Weber's Political Writings 15

3 The Political Context of Weber's Sociology 28

4 The Sociological Framework of Weber's

Political Thought $\quad 40$

5 Conclusion 54

$\begin{array}{ll}\text { Bibliography } & 60\end{array}$ 


\section{ACKNOWLEDGEMENTS}

\section{AND BIBLIOGRAPHICAL NOTE}

I should like to thank several persons who have read and commented helpfully on the first draft of this study: in particular, Martin Albrow, T. B. Bottomore, John Carroll and Steven Lukes.

References in the footnotes to works for which full details are given in the Bibliography simply quote author's name, date of the publication referred to, and page number where necessary, thus: Mommsen (1959) p. 118. All references which carry no author's name refer to works by Max Weber.

A. G. 